\title{
Standards for Faculty Status for
}

\section{College and University Librarians}

Adopted by the membership of the Association of College and Research Libraries, June 26, 1971, in Dallas, Texas.

With publication increasing at an exponential rate, with the variety of forms of publication proliferating rapidly, with significant scholarly and information material appearing in all the world's languages, with the bibliographical apparatus of many fields and subfields becoming increasingly difficult to use, with the growing sophistication of library and information technology, and with the development of academic libraries into large and complex organizations, the work of the academic librarian has become highly specialized and demanding.

The academic librarian makes a unique and important contribution to American higher education. He bears central responsibility for developing college and university library collections, for extending bibliographical control over these collections, for instructing students (both formally in the classroom and informally in the library), and advising faculty and scholars in the use of these collections. He provides a variety of information services to the college or university community, ranging from answers to specific questions to the compilation of extensive bibliographies. He provides library and information services to the community at large, including federal, state, and local government agencies, business firms and other organizations, and private citizens. Through his own research into the information process and through bibliographical and other studies, he adds to the sum of knowledge in the field of library practice and information science. Through membership and participation in library and scholarly organizations, he works to improve the practice of academic librarianship, bibliography, and information service.

Without the librarian, the quality of teaching, research, and public service in our colleges and universities would deteriorate seriously and programs in many disciplines could no longer be performed. His contribution is intellectual in nature and is the product of considerable formal education, including professional training at the graduate level. Therefore, college and university librarians must be recognized as equal partners in the academic enterprise, and they must be extended the rights and privileges which are not only commensurate with their contributions, but are necessary if they are to carry out their responsibilities.
In order to recognize formally the college or university librarian's academic status, the Association of College and Research Libraries and the American Library Association endorse, and urge all institutions of higher education and their governing bodies to adopt, the following standards for all academic librarians:

1. Professional responsibilities and self determination. Each librarian should be assigned general responsibilities within his particular area of competence. He should have maximum possible latitude in fulfilling these responsibilities. However, the degree to which he has fulflled them should be regularly and rigorously reviewed. A necessary element of this review must be appraisal by a committee of peers who have access to all available evidence.

2. Library governance. College and university libraries should adopt an academic form of governance. The librarians should form as a library faculty whose role and authority is similar to that of the faculties of a college, or the faculty of a school or a department.

3. College and university governance. Librarians should be eligible for membership in the academic senate or equivalent body at their college or university on the same basis as other faculty.

4. Compensation. The salary scale for librarians should be the same as that for other academic categories with equivalent education and experience. Librarians should normally be appointed for the academic year. If a librarian is expected to work through the summer session, his salary scale should be adjusted similarly to the summer session scale of other faculty at his college or university.

5. Tenure. Librarians should be covered by tenure provisions the same as those of other faculty. In the pretenure period, librarians should be covered by written contracts or agreements the same as those of other faculty.

6. Promotion. Librarians should be promoted through ranks and steps on the basis of their academic proficiency and professional effectiveness. A peer review system similar to that used by other faculty is the primary basis of judgment in the promotion process for academic librarians. The librarians' promotion ladder should 
have the same titles, ranks, and steps as that of other faculty.

7. Leaves. Sabbatical and other research leaves should be available to librarians on the same basis, and with the same requirements, as they are available to other faculty.

8. Research funds. Librarians should have access to funding for research projects on the same basis as other faculty.

9. Academic freedom. Librarians in colleges and universities must have the protection of academic freedom. Library resources and the professional judgment of librarians must not be subject to censorship.

To implement these standards, the Association of College and Research Libraries and the American Library Association will:

1. Publicize these standards to all colleges and universities and their libraries, all library schools, all library organizations, all higher education organizations, and all agencies which accredit academic institutions.

2. Seek to have these standards formally adopted or endorsed by all colleges and universities and their libraries, all library schools, all library organizations, all higher education organizations, and all agencies which accredit academic institutions.

3. Investigate all violations of these standards which are reported by members of the Association of College and Research Libraries. Such investigations will be coordinated and supervised by the Committee on Academic Status of the Association of College and Research Libraries.

4. Invoke the following sanctions against institutions of higher education which are found, after such investigation, to be in violation of any or all of these standards:

a. Publicize the violation and the institution concerned in CRL News and other appropriate publications.

b. Refuse to accept advertisements in any ALA publication for positions at that institution.

c. Discourage its members from accepting employment at that institution, through notices in its publications and other means.

A reasonable amount of time-three to five years-should be provided college and university libraries which do not currently conform to any or all of these standards, to enable them to do so. However, no such grace period should be provided to libraries which currently do conform, either wholly or in part, and which seek to deny or withdraw any such rights and privileges.

"The Committee on Academic Status receives, from individuals, reports of potential violations of these standards and recommends appropriate action to the ACRL Board of Directors. Requests for assistance from individuals who allege that violations of these standards have occurred are within the jurisdiction of the ALA Program of Action for Mediation, Arbitration, and Inquiry, and should be directed to the Executive Director of the American Library Association.

Single reprint copies of these standards are available from the ACRL Office, $50 \mathrm{E}$. Huron St., Chicago, IL 60611. Multiple copies are 20ф each.

\section{Two-Year Guidelines in A-V Format}

The "Guidelines for Two-Year College Learning Resources Programs" (CRL News, December 1972), prepared and approved in 1972 by ACRL, the American Association of Community and Junior Colleges, and the Association for Educational Communications and Technology, are now illustrated in an audiovisual presentation. The program, prepared by the AACJC/AECT/ALA(ACRL) Joint Committee on Learning Resources Programs, is intended for use by educators and lay persons. It will also be useful in in-service programs for learning resources personnel.

The presentation is available either as a synchronized audio cassette/slide program or on a ${ }^{3}$-inch U-Matic color video cassette. It can be obtained on interlibrary loan from the ALA Headquarters Library. Arrangements have been made with Johnson County Community College, in Overland Park, Kansas, to furnish copies for sale to those who prefer to purchase the program. Since the presentation is not copyrighted, it may be duplicated by the borrower or purchaser.

Interlibrary loan requests should be addressed to: ALA Headquarters Library, 50 E. Huron St., Chicago, IL 60611. Purchase orders (slide/tape, $\$ 25.00$; video cassette, $\$ 27.50$ ) should be addressed to: Educational Media Center, Johnson County Community College, 111th \& Quivira Road, Overland Park, KS 66210 . All requests should specify the format desired. 